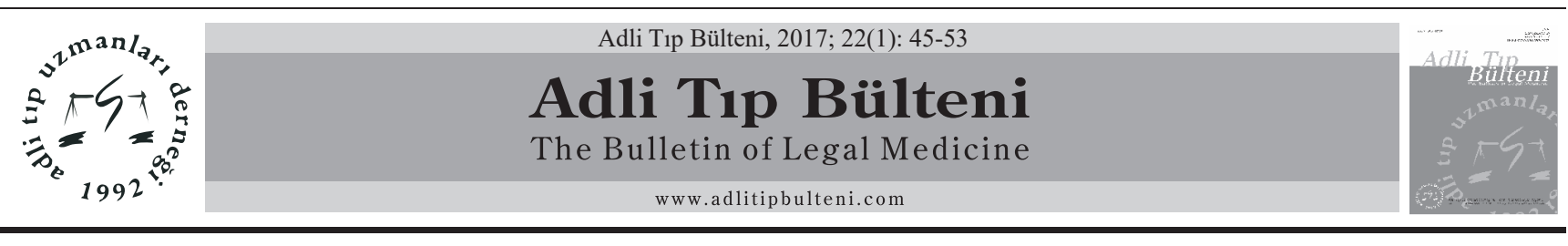

\title{
Yaralama Suçlarının Adli Tıbbi Değerlendirilmesinde Kullanılan Kılavuza Bakış
}

\section{An Overview of The Guide Used for Medicolegal Evaluation of Injury Crimes}

\author{
Ekin Özgür Aktaş, Ahsen Kaya \\ Ege Üniversitesi Tıp Fakültesi Adli Tıp Anabilim Dalı, İzmir
}

\begin{abstract}
Özet
Yaralama suçları, yaygınlığı nedeniyle tıbbi açıdan değerlendirilen suçların önemli bir bölümünü oluşturmaktadır. Adli soruşturma ve yargılamalarda yaralanan bireylerdeki lezyonların değerlendirilip rapor edilmesi, dikkat edilmesi gereken ve sorumluluk doğuran bir görevdir. $\mathrm{Bu}$ yazıda, yaralama suçlarının adli tıbbi raporlanmasında uygulama birliği yaratılması amacıyla oluşturulmuş kılavuz incelenerek, güncel gelişmeler 1şı̆̆ında görüş, eleştiri ve öneriler sunulmuştur.
\end{abstract}

Anahtar Kelimeler: Yaralama; Suç; Rapor.

\begin{abstract}
Due to their prevalence, injury crimes constitute a substantial part of crimes evaluated medically. Assessment and reporting of the lesions in injured individuals during investigation and adjudication is a significant assignment incurring liability. In this article, in the light of recent developments we present our opinions, critics and suggestions regarding the guide put together with the purpose of securing uniformity between forensic reporting practices.
\end{abstract}

Keywords: Injury; Crime; Report.

\section{Giris}

Yaralama suçlarının cezalandırılması eski dönemlerden beri varlığını sürdürmektedir. Eskiden kısasa kısas olarak uygulanan cezalandırma yöntemleri sonraki dönemlerde toplumsal yapı ve hukuk kurallarının gelişmesi ile devletler tarafindan cezalandırılır hale gelmiştir.

Roma hukukundan etkilenen ve Avrupa hukuk uygulamalarının çekirdeğini oluşturan Germen hukuku ve buna eklemeler yapılarak geliştirilen tüm modern hukuk sistemlerinde de yaralama fiilleri suç olarak tanımlanmış ve cezalandırılmaları öngörülmüştür. Yaralama suçlarında, oluşan yaralanmaların tipi, bölgesi ve sekel bırakıp bırakmayacağı, diğer bir ifade ile yaralanmaların ağırlığı, cezaların belirlenmesinde dikkate alınan unsurlardan biri olmuştur.

Cumhuriyetin kurulmasından sonra, kuruluş yıllarına özgü sorun ve imkânlar nedeniyle yeniden bir kanun yapmak yerine dönemin en modern görülen kanunlarının iktisabı yolu tercih edilmiş ve İtalyan Ceza Kanunu iktisap edilerek yürürlüğe sokulmuştur (1). Uzun yıllar üzerinde ihtiyaçlarına göre değişiklikler yapılarak yürürlükte kalan 765 sayılı Türk Ceza Kanunu (TCK) hükümleri yaralanma fiillerinin değerlendirilmesinde esas alınmıştır. 765

Sorumlu Yazar: Ekin Özgür Aktaş

Ege Üniversitesi Tip Fakültesi Adli Tip Anabilim Dalı, İzmir

E-posta:eoaktas@yahoo.com

Geliş:16.03.2016 Düzeltme:06.02.2017 Kabul:20.02.2017 sayılı TCK hükümlerine dayanılarak yapılan yaralama suçlarının adli tıbbi değerlendirmeleri, uygulandığı döneme ait bilimsel bilgiler ve Yargıtay kararları ile oldukça standartlaştırılmış şekilde yapılmaktaydı.

Avrupa Birliğine başvurunun hızlandığı müktesebat (edinilen-kazanılan bilgiler-yasal düzenlemeler) uyumu sürecinde, tüm alanlarda olduğu gibi Ceza hukuku alanında da modern bir düzenleme yapılması ihtiyacı ortaya çıkmıştır. Bu ihtiyaç nedeniyle Türk Ceza Kanunu (Kanun No:5237) da yenilenerek Türkiye Büyük Millet Meclisi tarafından 26.09.2004 tarihinde kabul edilmiş ve 01.06.2005 tarihinde yürürlüğe girmiştir (2).

5237 sayılı TCK'da yaralanma suçları ile ilgili temel yaklaşım, yerine geçtiği 765 sayılı TCK ile bazı hususlarda benzerlik arz etmesine rağmen bazı yenilik veya farklı değerlendirme gerektiren düzenlemeler de getirmiştir. 5237 sayılı TCK'da yaralama suçlarına ait değerlendirmelerde esas alınacak hususlar 86.-89. maddelerde yer almaktadır (2). Aradaki benzerlikler ve farklılıkların anlaşılabilmesi için her iki ceza kanununda yer alan düzenlemeler tabloda karşılaştırılmıştır (Tablo 1).

Yukarıda da kısaca karşılaştırıldığı gibi yaralama suçlarının değerlendirilmesinde iki kanun arasında belli oranda uyum olup, eski kanunda yer alan ifadelerin Türkçeleştirildiği görülmektedir. Ancak, daha az veya ağır cezay1 gerektiren nitelikli haller düzenlenirken anlam farklılığı yaratacak bazı yeni ve önemli düzenlemelere gidildiği görülmektedir. 
Tablo 1. 765 sayılı TCK ile 5237 sayılı TCK karşılaştırılması.

\begin{tabular}{|c|c|}
\hline 765 Sayılı TCK (Mülga) & 5237 Sayılı TCK \\
\hline \multicolumn{2}{|c|}{ Suçun Temel Şekli } \\
\hline $\begin{array}{l}\text { Katil kastiyle olmaksızın bir kimseye cismen eza verme } \\
\text { veya sıhhatini ihlal yahut akli melekelerinde teşevvüş } \\
\text { husulüne sebep olma }\end{array}$ & $\begin{array}{l}\text { Kasten başkasının vücuduna acı verme veya sağlığının ya } \\
\text { da algılama yeteneğinin bozulmasına neden olma }\end{array}$ \\
\hline \multicolumn{2}{|c|}{ Suçun Daha Hafif Ceza Gerektiren Hali } \\
\hline $\begin{array}{l}\text { Eğer fiil, hiçbir hastalığı veya mutat iştigallerden } \\
\text { mahrumiyeti mucip olmamış olması yahut bu hallerin on } \\
\text { günden ziyade uzamamıș olması }\end{array}$ & $\begin{array}{l}\text { Kasten yaralama fiilinin kişi üzerindeki etkisinin basit } \\
\text { bir tıbbi müdahaleyle (BTM) giderilebilecek ölçüde hafif } \\
\text { olması (Sadece kasten yaralama suçlarında-TCK Md. 86/2) }\end{array}$ \\
\hline
\end{tabular}

günden ziyade uzamamış olması

Suçun Daha Ağır Cezayı Gerektiren Nitelikli Halleri

\begin{tabular}{|c|c|}
\hline Kişinin hayatını tehlikeye maruz kılması & Yaşamını tehlikeye sokan bir duruma neden olması \\
\hline $\begin{array}{l}\text { Havastan veya azadan birinin devamlı zaafina neden } \\
\text { olmas } 1\end{array}$ & $\begin{array}{l}\text { Duyularından veya organlarından birinin işlevinin sürekli } \\
\text { zayıflamasına neden olması }\end{array}$ \\
\hline Çehrede sabit bir eser oluşması & Yüzünde sabit ize neden olması \\
\hline Çehrenin daimi değişikliğine neden olması & Yüzünün sürekli değişikliğine neden olması \\
\hline Söz söylemekte devamlı müşkülat oluşması & Konuşmasında sürekli zorluğa neden olması \\
\hline Söylemek kudretinin zıyaına sebep olması & Konuşma yeteneklerinin kaybolmasına neden olması \\
\hline $\begin{array}{l}\text { Gebe bir kadın aleyhine işlenip de vaktinden evvel çocuk } \\
\text { doğmasını intaç etmesi }\end{array}$ & $\begin{array}{l}\text { Gebe bir kadına karşı işlenip de çocuğunun vaktinden } \\
\text { önce doğmasına sebep olması }\end{array}$ \\
\hline $\begin{array}{l}\text { Gebe bir kadına karşı ika olunup da çocuğun düşmesini } \\
\text { intaç eylemesi }\end{array}$ & $\begin{array}{l}\text { Gebe bir kadına karşı işlenip de çocuğunun düşmesine } \\
\text { sebep olması }\end{array}$ \\
\hline Çocuk yapmak kabiliyetinin zıyaına sebep olması & Çocuk yapma yeteneklerinin kaybolmasına neden olması \\
\hline $\begin{array}{l}\text { Fiilin gizli veya aşikar bir silah ile veya aşındırıcı ecza ile } \\
\text { işlenmesi }\end{array}$ & Silâhla işlenmesi \\
\hline $\begin{array}{l}\text { Yirmi gün ve daha ziyade akli veya bedeni hastalıklardan } \\
\text { birine veya bu kadar müddet mutat iştigallerine devam } \\
\text { edememesine mucip olma }\end{array}$ & Yoktur \\
\hline Yoktur & $\begin{array}{l}\text { Kasten yaralamanın vücutta kemik kırılmasına veya } \\
\text { çıkığına neden olması halinde, kırık veya çıkığın hayat } \\
\text { fonksiyonlarındaki etkisi (Sadece Kasten Yaralama fiili } \\
\text { için Md. 87/3) }\end{array}$ \\
\hline Yoktur & $\begin{array}{l}\text { Vücudunda kemik kırılmasına neden olma (Sadece } \\
\text { Taksirle Yaralama fiili için Md. 89/2b) }\end{array}$ \\
\hline
\end{tabular}

Yaralama suçları ile ilgili düzenlemeler, ceza hukukuna hakim olan kanunilik ilkesi ve 5237 sayılı TCK'nın “Adalet ve Kanun Önünde Eşitlik İlkesi” kenar başlıklı 3. maddesinde yer alan "Suç işleyen kişi hakkında işlenen fiilin ağırlığıyla orantılı ceza ve güvenlik tedbirine hükmolunur" ifadesinde de belirtildiği üzere orantılılık ilkesi 1ş1ğında incelendiğinde kişilerin vücutlarında oluşan ve bilirkişilerce belirlenip rapor edilen travmatik bulgulara dayanılarak cezanın kasten yaralamalarda üç kategori halinde uygulanmasının amaçlandığı görülmektedir. Buna göre;

\section{a. Azaltılmış Ceza Uygulanması Öngörülen Hali}

- Kasten yaralama suçlarında en hafif ceza öngörülen, en basit olarak değerlendirilen yaralanmalar: "Kasten yaralama fiilinin kişi üzerindeki etkisinin basit bir tıbbi müdahaleyle giderilebilecek ölçüde hafif olması halinde, mağdurun şikayeti üzerine, dört aydan bir yıla kadar hapis veya adli para cezasına hükmolunur.” şeklinde ifade edilmiştir (TCK Md. 86/2).

- Bu düzenleme ile suçun temel şekline göre daha az bir ceza verilmesi amaçlandığına göre oluşan yaralanmanın ağırlığının da, suçun temel şekline göre daha hafif olması gerektiği açık bir şekilde anlaşılmaktadır.

\section{b. Yaralama Suçunun Temel Hali}

- Kasten yaralama fiilinin temel şekli: "Kasten başkasının vücuduna acı veren veya sağlığının ya da algılama yeteneğinin bozulmasına neden olan kişi, bir yıldan üç yıla kadar hapis cezası ile cezalandırılır" şeklinde belirtilmiştir (TCK Md. 86/1). 
- Bu genel tanım içine giren yaralanmaların basit bir tıbbi müdahale ile giderilebilecek ölçüde hafif olması halinde daha az ceza öngörülmüş olması nedeniyle, suçun temel şeklinin basit bir tıbbi müdahale ile giderilebilecek ölçüde hafif olmayan ağırlıkta olan "vücuda acı veren, sağlığı ve algılama yeteneğini bozan yaralanmaları" ifade ettiği sonucuna varılmaktadır.

\section{c. Arttırılmış Ceza Uygulanması Öngörülen Hali}

- Kasten yaralama suçunun daha fazla ceza gerektiren nitelikli halleri: TCK'nın $86 / 3$. ve 87 . maddelerinde belirtilen nitelikli hallerin söz konusu olması halinde cezanın ağırlaştırılarak uygulanması düzenlenmiştir.

\section{Taksirle Yaralama Suçları}

- Taksirli suçlar için yapılan düzenlemede, kasten yaralama fiillerine benzer bir değerlendirme yapılmakla birlikte önemli bazı farklılıklar da söz konusudur.

- Bunlar;

i. Taksirli suçlarda "Basit bir tıbbi müdahale ile giderilebilecek ölçüde hafif olma" kavramından bahsedilmemektedir. Bu nedenle, taksirli suçlara ait raporlamalarda bu hususun değerlendirilmesine gerek kalmamaktadır.

ii. TCK'da taksirli suçlar için kırıkların hayat fonksiyonlarına etkisi ile ilgili bir düzenleme olmadığından bu hususun da değerlendirilmesi gereksizdir. Taksirli suçlarda kemik kırıklarının sadece var olup olmadığının raporlanması yeterli olmaktadır.

iii. Taksirli yaralamalarda, kasten yaralama suçlarından farklı olarak çıkıklara da yer verilmediği görülmektedir.

\section{2. "Türk Ceza Kanunu'nda Tanımlanan Yaralama Suçlarının Adli Tıp Açısından Değerlendirilmesi”’ başıklı kılavuzla ilgili süreç}

5237 sayılı TCK'nın yürürlüğe girmesinden sonra, uzunca yıllar uygulanan, alışkanlık ve uygulama birliğinin genel olarak sağlandığı 765 sayılı TCK uyarınca yaralanma değerlendirmelerinin de yeni düzenlemeye uygun yapılması zorunluluğu ortaya çıkmıştır. Uygulamada birlik sağlanması ve sıkıntı yaşanmaması için daha önceki uygulamaların da 1şığında Haziran 2005 tarihinde "Adalet Bakanlığı Adlî Tıp Kurumu Başkanlığı, Adlî Tıp Uzmanları Derneği ile Adlî Tıp Derneği tarafından (Uzm. Dr. Sadullah Güzel, Doç. Dr. Yasemin Balcı ve Prof. Dr. Gürsel Çetin editörlüğünde) "Yeni Türk Ceza Kanunu'nda Tanımlanan Yaralama Suçlarının Adlî Tıp Açısından Değerlendirilmesi” başlıklı metin hazırlanmış ve bunun "Sağlık Bakanlığı tarafindan adlî tıp hizmeti sunan sağlık personelinin bilgilendirilmesi amacıyla bi- çimsel yönden düzenlenmiş hali" olduğu ifade edilmiştir (3). Türk Ceza Kanununun Yürürlük ve Uygulanması Hakkında Kanun'da bu tür bir kılavuz hazırlanması ile ilgili bir düzenleme olmadığından, bu kılavuz başlangıçta bir öneri niteliğinde alana sunulmuştur $(2,4)$. Türk Ceza Kanununda yer alan düzenlemeler ve uygulamalar ışığında yukarıda belirtilen ve özellikle Sağlık Bakanlığ tarafindan adli tıp hizmeti sunan personelin bilgilenmesi amacına yönelik hazırlandığı vurgulanan metin daha sonra Sağlık Bakanlığınca bir genelge ekinde yayımlanmış (5) ve yaralama suçları ile ilgili yapılan değerlendirmelere esas alınmaya başlanmıştır. Kılavuz 19.06.2006 tarihinde revize edilmiş olup, güncel ihtiyaçlar 1şığında en son Haziran-2013 tarihinde güncellenmiştir ve halen bu metin kullanılmaktadır.

Sağlık Bakanlığının 2005/143 sayılı genelge ekinde gönderdiği ve uygulanmasını istediği ilk kılavuz ve ekli rapor formatlarında, yukarıda da belirtildiği üzere sonradan bazı güncelleme ve değişiklikler yapılması üzerine, 2014 yılında yayımladığ revizyonlarındaki güncel düzenlemelere uyulması istenmiştir (6).

Kısaca özetlendiği üzere ilgili kılavuz, yaralama suçlarının değerlendirilmesi ile ilgili yaygın olarak yararlanılan bir kılavuz niteliğindedir. Ancak, kılavuzun hazırlanması sırasında 765 sayılı TCK döneminde yapılan uygulamalardan fazla esinlenilmesi, ceza hukuku doktrininde oluşturduğu derin görüş yeniliğini tam yansıtmaması, uygulamada bazı sorunları da beraberinde getirmiştir. $\mathrm{Bu}$ kılavuzun yaralama suçlarını değerlendirmeye yönelik bilirkişi raporlarında esas alınması ve bu raporların TCK içinde yer alan özellikle nitelikli halleri yorumlamada temel dayanak olması, uygulamadaki sıkıntıları arttırmış, yukarıda da açıklandığı üzere bazı değişiklikler yapılarak kılavuz iki kez güncellenmiştir. Sıkıntıların devam etmesi nedeniyle revizyon çalışmalarına halen devam edilmektedir.

Kılavuzdaki revizyonlara başka bir makale konusu olması sebebiyle ayrıntıya girilmeden teknik olarak şu eleştiri getirilebilir. 5237 sayılı Türk Ceza Kanunu yaralanmalar açısından değişmiş olmasa da kılavuzdaki yorum ve nitelemelerin değiştirilmesi adli raporlarda belirtilen hususların özellikle nitelikli hallerin değişmesine neden olabilmektedir. Yani kılavuzda yapılan revizyonlarla, aynı lezyonlar nitelikli hal sayılabilmekte veya nitelikli hal sayılmaktan çıkarılabilmektedir. Ceza tayininde önemli değişikliklere neden olabilecek bu revizyonlar öncesi düzenlenen raporlara göre yapılan yargılama işlemlerinde, derdest dava veya infazı henüz bitmemiş hükümlerde lehe bir değişiklik söz konusu olduğunda bunun nasıl uygulamaya sokulacağı belli değildir. Yani kıla- 
vuzda yapılan değişiklikler, cezanın belirlenmesi ile ilgili süreci de değiştirerek faillere daha ağır veya hafif bir ceza verilmesine neden olabilecek sonuç doğurma potansiyeli taşımaktadır. Bu bağlamda, yargılama süreçleri ve ceza süreleri üzerinde bu denli önemli bir etki doğuracak değişiklikleri yapma yetkisi ve özellikle lehe sonuç doğurabilecek revizyonların etkisinin halen devam eden dava ve infazlarda nasıl dikkate alınacağı hususu belli değildir.

Yukarıda kısaca açıklandığ masında, 765 sayılı TCK uygulamalarından fazla esinlenilmesi ve yeni kavramlardaki farklılıkların yeterince dikkate alınmaması uygulamadaki sıkıntıları bitirememiştir. Adli tıbbi değerlendirmelerin kanundaki düzenlemeler ile tam uyuşmaması yargılama hatalarına ve itirazlara neden olmaktadır. Bu makalede kısaca en sıkıntılı noktalar üzerinde durulacak ve çözüm önerilerinde bulunulacaktır.

\section{Kılavuzda Yer Alan Düzenlemeler, Eleştiriler ve Öneriler:}

\section{3a. Suçun Temel Şeklinde Yer Alan "Algılama Ye- teneğinin Bozulmasına Neden Olan" kavramının "Psikiyatrik Rahatsızlıklarla" Karıştırılması:}

Kılavuzun açıklama kısmında açık bir şekilde "Kişinin să̆lı̆̆ın ya da algılama yeteneğini bozacak derecedeki yaralanma" tanımı, travmanın ruhsal etkilerini de kapsamaktadır. Kişilerin uğradığı travma sonrası oluşan ruhsal sağglı zararı da TCK kapsaminda tanımlanmıştır. Travma sonrasi oluşan ruhsal zarartn belirlenmesine yönelik kriterler ekli listede yer almaktadır." şeklindeki açıklamadan "algılama yeteneğinin bozulması" kavramının ruhsal sağlık zararı, ekli liste de göz önünde bulundurulduğunda özellikle ruhsal hastalıklar şeklinde alg1landığı görülmektedir. Oysa ruhsal zararlar ile algılama yeteneğinin bozulması farklı kavramlardır.

Algılama yeteneği TCK' da birçok farklı madde içinde zikredilen bir kavramdır (Madde 31, 84, 86, 89, 94, 103, 158). Gerek madde metinleri, gerek madde gerekçeleri incelendiğinde, bu kavramın herhangi bir ruhsal zarar (hastalık oluşması) anlamında ifade edilmediği açık bir şekilde anlaşılmaktadır.

Algılama; sözlükteki en basit anlamıyla "anlama yeteneği, anlayış, akıl erdirme, idrak" anlamına gelmektedir. Kişilerin dış dünyada gelişen olayları doğru anlayıp, yorumlama ve onları doğru bir şekilde değerlendirme yeteneklerini ifade etmektedir. Algılama yeteneğinin bozulmasına neden olma kavramı, travmanın kişilerin anlama, değerlendirme ve idrak edebilme yeteneklerinin bozulmasını ifade etmektedir. Algılamanın bozulmasının, mutlaka bir ruhsal zarar veya hastalığa bağlı olması veya böyle bir durumla sonuçlanması şart değildir. İki kavram birbirinden farklı ve bağımsızdır. Oysa kılavuzda açık bir şekilde "algılamanın bozulması" kavramının "ruh sağlığında bozulma" şeklinde değerlendirdiği ifade edilmektedir. Bu nedenle, algılama yeteneğini bozan birçok durum değerlendirilememektedir. Şüphesiz ki travma sonrası bazı ruhsal zararların (hastalıkların) oluşması mümkündür. Kanaatimizce, travmaya bağlı hafif ruhsal bozukluklar "sağlığın bozulması", kalıcı ve ağır ruhsal bozukluklarda da "iyileşmesi mümkün olmayan hastalığa neden olma" açısından değerlendirilmelidir.

\section{3b. Basit Tıbbi Müdahale (BTM) Kavramı:}

"Basit bir tıbbi müdahale ile giderilebilecek ölçüde hafif olma", "kasten başkasının vücuduna acı verme" veya "sağlığının ya da algılama yeteneğinin bozulmasına neden olma" olarak tanımlanan, kasten yaralama suçunun temel halinin, en hafif hali olarak düzenlemiştir (2). Bu kavramla, ölçülülük ilkesi gereğince suçun temel hali için öngörülen ve res'en soruşturulan bir yıldan üç yıla kadar hapis cezası yerine, şikayete bağlanan ve 4 aydan bir y1la kadar hapis cezası veya adli para cezası yaptırımı öngörülen bu durum ifade edilmektedir.

Kılavuzda da "Adli yönden, hangi travmatik değişimlerin basit bir tıbbi müdahale ile giderilebilecek ya da giderilemeyecek olduğu konusunda tüm hekimler tarafindan kullanılabilecek bir listeye ihtiyaç vardır. Ekli liste oluşturulurken, basit tıbbi müdahalelerin ne olduğu, nelerin basit trbbi müdahale ile giderilebileceğinden öte, hangi travmatik değişimlerin hafif derecede yaralanmalar içinde yer alması gerektiği gözetilmiştir" ifadesinden travma sonucu yaralanmaların değerlendirilmesinde tıbbi girişim gerekip gerekmemesinden ziyade, yaralanma ağılığının dikkate alındığı ifade edilmektedir.

Kılavuzdaki örnekler dikkate alındığında, 765 sayılı TCK'nun uygulamasında 10 günden az süre mutat iştigale mani teşkil eder nitelikte yaralanmaların [herhangi bir kırık, çıkık, iç organ yaralanması, büyük damar yaralanması olmayan, sıyrık, ekimoz, cilt bütünlüğünü bozan lasere ya da kesici tipte sütür gerektiren yaraların (7) BTM ile giderilebilir yaralanmalar olarak kılavuza aktarıldığ görülmektedir.

BTM ile giderilebilir lezyonlardan bahsedilmesi nedeniyle, Adli Tıp Uzmanı olmayan kişilerce, bazı durumlarda yaralanmanın tıbbi müdahale gerektirmesi gibi yanlış bir alg1 oluşabilmektedir. Bu alg1, kot kırığg gibi kimi durumlarda herhangi bir tıbbi müdahale söz konusu olmasa bile yaralanmanın basit bir tıbbi müdahale ile giderilebilecek ölçüde hafif olmaması durumu ile ters düşmektedir.

Kılavuzda yer alan listelerde sadece sınırlı sayıda lezyon/lezyon grubu BTM ile giderilebilir olarak listelenmiştir. Şüphesiz ki tüm lezyonların listelere alınması 
mümkün değildir ancak bunlarla aynı ağırlıkta veya daha hafif bazı lezyonların listelerde yer almamış olması, bu tür lezyonların uygulamada Basit Tıbbi Müdahale ile giderilemez şeklinde değerlendirilmesine yol açabilmektedir. Bu nedenle, bu konuda genel değerlendirme yapılmasını kolaylaştıracak yorumların kılavuzda arttırılması faydalı olacaktır.

Yukarıda belirtilen hususlar dışında kılavuzda BTM ile giderilebilir olarak belirtilen sınırlı durumlar için de bazı sıkıntılar söz konusudur.

- Öncelikle belirtilen lezyonların, TCK sistematiği ve kılavuzdaki açıklama gereğince en hafif yaralanma tipleri olmas1 gereklidir. Ancak BTM ile giderilebilir olduğu belirtilen bazı lezyonların bu şekilde nitelenmesi mümkün değildir. Örneğin, kılavuzda "cilt-cilt altı yaralanmalarda belirlenen $10 \mathrm{~cm}$.lik tek bir lezyon veya vücudun neresinde bulunursa bulunsun birden fazla ve toplam 20 cm boyutunu geçmeyen lezyonlar" BTM ile giderilebilir olarak belirtilmiştir. Ancak küçük ve önemsiz olmakla birlikte birden fazla lezyonun toplamının $20 \mathrm{~cm}$ 'i geçtiği durumlarda BTM ile giderilemez olarak değerlendirme yapilırken, tek ve daha ağır olmakla birlikte, 10 santimi geçmeyen tek bir lezyon BTM ile giderilebilir olarak raporlanmaktadır. Bu tip durumlar yaralanmaların ağırlığının objektif şekilde değerlendirilmesinde sıkıntı yaratacak özelliktedir. Birden çok lezyonda boyut toplamlarının hangi tıbbi gerekçeyle kılavuza alındığı anlaşlamamaktadır.

- Yaralanmanın kendisine değil de yaralanma bölgesine verilen değerin tıbbi, mantıki ve hukuki gerekçesi yoktur. Cilt-cilt altı yaralanmanın tek yaralarda yüz bölgesindeyse $5 \mathrm{~cm}$, diğer bölgelerinde ise $10 \mathrm{~cm}$ 'den fazla olmasının BTM ile giderilemez olarak değerlendirilmesinin hangi ölçüte dayanılarak belirlendiği açık değildir.

- Bir diğer örnek, yaşın dikkate alınmasıdır. Örneğin, 2. derece yanıklarda beş yaş altı ve üstü için farklı yanık yüzdelerin belirlenmesi nedeniyle, $\% 7$ yanığa neden olan bir fail, mağdur beş yaşından büyükse farklı, küçükse farklı bir ceza ile karşı karşıya kalmaktadır. Cezada eşitliği ortadan kaldıran bu durumun ceza hukukunun temel ilkeleri ile ne denli örtüştüğü tartışmalıdır.

- Yine yaralanmanın silah ile oluşması halinde nitelikli bir hal söz konusu olduğu halde, özellikle kesici aletler ile oluşan cilt-cilt altı yaralanmalarının BTM ile giderilebilir olarak raporlanması söz konusu olabilmektedir.

- Daha ağır ceza gerektirecek nitelikli hale sebep olma olasılığı bulunan bazı lezyonlar kılavuza BTM ile giderilebilir olarak aktarılmıştır. Örneğin, yüzde sabit ize neden olması mümkün olan yüz bölgesinde $5 \mathrm{~cm}$ 'den daha kısa cilt-ciltaltı yaralanması, kulak memesindeki kısmi lezyonlar, yanıklar vb. ilk raporlarda BTM ile giderilebilir olarak rapor edilebilmektedir. Daha sonra yüzde sabit iz olduğunun anlaşılması halinde ise nitelikli hal nedeniyle temel hale nazaran daha ağır ceza gerektiren bir durum ortaya çıkmaktadır. Bu durum hem aradan geçen sürede yapılan usul işlemlerini değiştirmekte, hem de daha hafif ve daha ağır ceza gerektiren nitelikli hallerin aynı raporda yer alması gibi bir çelişkiye neden olmaktadır.

BTM ile giderilebilir değerlendirmesi ile ilgili önerimiz şu şekildedir;

- Basit bir tıbbi müdahale ile giderilebilecek ölçüde hafif olan lezyonlar sınırlı sayıda örnekle belirtilmemelidir.

- Lezyonlarda, lokalizasyon ve yaş gibi kriterler olmamalıdır.

- Bunun yerine; vücudun neresinde olursa olsun " $k l$ rlğa veya suçun nitelikli hallerine (yüzde sabit iz, duyu veya organlarda zayıflama-kayıp vb) sebep olmamış", "yaşamsal fonksiyonlarl olumsuz etkilememiş", "hastanede yatışa ve girişime sebep olmamış", "sekel bırakma riski bulunmayan", "10 cm.i geçmeyen cilt-ciltaltı yaralanmaları, ekimozlar" "Vücut alanının \% 5 'ini geçmeyen slyrıklar ve 1 veya 2 . derece yanıklar", "kirığa neden olmayan burkulma ve kontüzyonlar", "herhangi bir nörolojik bulgu yaratmayan, kısa süreli-geçici bilinç kaybıamnezi yaratan ve spontan olarak 24 saat içinde iyileşen kafa travmaları" BTM ile giderilebilir olarak nitelendirilmelidir.

- Uygulamada Yargıtay kararları da dikkate alınarak çelişki yaratmaması açısından; "yüz sınırları içindeki yaralanmalar" ve "fonksiyon kaybina neden olabilecek lezyonlar" uygun süre beklendikten sonra değerlendirilmeli, "silahla oluşan yaralanmalar" ise BTM ile giderilebilir olarak nitelendirilmemelidir.

\section{3c. Yüzde Sabit İz Oluşturabilmesi Muhtemel Lezyonların BTM Açısından Değerlendirilmesi:}

Travmaların değerlendirilmesinde öncelikle ve ilk olarak travmanın kişinin yaşamını tehlikeye sokan bir duruma neden olup olmadığ ölçüde hafif olup olmadığı değerlendirilmektedir. Travma sonrası yapılan bu değerlendirmelerde yüz bölgesinde yer alan bazı yaralanmalar BTM ile giderilebilir olarak rapor edilmekte ve kılavuz uyarınca yüzde sabit iz niteliğinde olup olmadığı açısından uygun bir süre beklenmesi yoluna gidilmektedir. BTM ile giderilebileceği belirtilen bazı lezyonlar daha sonra yapılan değerlendirmelerde yüzde sabit iz olarak rapor edilmektedir. Bu durumlarda ilk raporda yaralama suçunun en hafif hali olarak rapor edilen lezyon (yaralama), ikinci raporda nitelikli bir hal olarak tekrar rapor edilmektedir. Bu çelişki, bekleme süresi içinde ön rapora göre yapılan hukuki işlemlerin de ha- 
talı olmasına neden olmaktadır. Bu nedenle, yüz sınırları içinde bulunan ve yüzde sabit iz oluşturup oluşturmayacağı konusunda mutlaka beklenmesi gereken lezyonların BTM açısından ön raporlarda değerlendirilmemesi uygun olacaktır. Yüzde sabit iz niteliğindeki bir yaralanmanın basit bir tıbbi müdahale ile giderilemeyecek nitelikte bir yaralanma olarak belirtilmesi gerektiği ile ilgili Yargıtay kararları da mevcuttur (8-9).

\section{3d. Yüzde Sabit İz Değerlendirilmesinde Karşılaşılan Zorluklar:}

Yüz sınırları açısından 765 sayılı TCK ve 5237 sayılı TCK'da yer alan düzenlemeler açısından fark bulunmaktadır. Yeni düzenlemede saçların dökülmesi ile karşıdan bakıldığında görülebilen sınır ile boyun ön kısmı yüz s1nırları içine dahil edilmiştir. Bu sınırlar içinde yer alan yaranın iyileştikten sonra bıraktığı iz, gün 1şığında veya iyi aydınlatılmış bir ortamda, insanlar arası sözel diyalog mesafesinden (1-2 metre) ilk bakışta belirgin bir şekilde fark edilebilir durumda ise 'yüzde sabit iz"den bahsedilir (3).

Kılavuzda bu değerlendirmenin en az 6 ay sonra yapılması, hekimin gerekli gördüğünde bu süreyi uzatması önerilmiş ise de uygulamada da genellikle 6 ay sonra yapılan değerlendirme ile karara varılmakta olup bu sürenin gerektiğinde uzatılabileceği hususu genellikle göz önünde bulundurulmamaktadır.

Meydana gelen yaraların iyileşmesi birçok faktörden etkilenebilmekte ve kişisel farklılıklar gösterebilmektedir. Yara oluşmasından hemen sonra dokularda tamir süreci başlamaktadır. Yara iyileşmesi yaranın ilk iyileşme dönemi (primer yara iyileşmesi) ve dokuların yeniden eski direnç ve yapılarına döndüğü dönem (sekonder yara iyileşmesi-remodelling) olarak değerlendirilmektedir. Dokuların eski direnç ve yapılarına dönme süreci (yeniden şekillenme fazı- remodelling) daha uzun sürmekte ve yara izinin son halini alması bazen yıllarca sürebilmektedir (10). Ancak bazı kişilerde skar (nedbe) bölgesinde belirgin düzey farklılığı gösteren keloid doku veya belirgin renk farklılığı gösteren hiperpigmentasyon oluşması sıklıkla görülebilmektedir. Altı ay sonra yapılacak değerlendirmelerde kolaylıkla yüzde sabit iz olarak rapor edilebilecek bu lezyonlar yeniden şekillenme fazı sürecinde zamanla kendiliğinden belirgin durumlarını kaybedebilmektedir. Yeterli ve uygun süre beklenilmeden yapılan raporlamalarda oluşan skarların daha ağır cezayı gerektiren nitelikli hale yol açtığ 1 ifade edilerek rapor edilmesi ve sonuçta hatalı kararlara neden olması mümkündür. Bu nedenle özellikle iyileşme fazına özgü değişikler görülen yara izlerinde (hiperpigmentasyon, keloid doku vb.) değerlendirmelerin yara iyileşmesi tamamlanıncaya kadar (6 ay geçmiş olsa bile iyileşme tamamlanmamışsa daha uzun süre) izlenmesi gerekliliğinin mutlaka k1lavuzda vurgulanması, değerlendirmeyi yapan kişinin takdirine bırakılmaması gereklidir.

\section{3e. "Organdaki veya ekstremitedeki anatomik} kayıp ve/veya fonksiyonel bozukluğun o organ veya ekstremitenin kendi anatomik yapısı ve/veya fonksiyonuna göre \% 10-50 arasında ise "işlevin sürekli zayıflaması"; \% 50'nin üzerinde ise "işlevin yitirilmesi”" olarak değerlendirilmesi”:

TCK'ya göre yaralama suçlarının cezalandırılmasında duyu ve organların işlevinde zayıflama veya kayıplar ağırlaştırıcı sebep olarak nitelendirilmiştir.

Duyu kavramı üzerinde fazla tartışma olmamakla birlikte, organ nitelemesi üzerinde aynı netlikte bir görüş oluşturulamadığ1 görülmektedir. Organ kavramı "vücudun belirli bir görevi yapan ve sınırları kesin olarak belirlenmiş bölümü’dür. Kılavuzda uygun bir şekilde çift organların ayrı-ayrı fonksiyonlarına göre değerlendirileceği, ekstremitelerin de bölümlerinin (el, önkol, kol, ayak, bacak, kalça) ayrı ayrı değerlendirileceği belirlenmiştir.

Burada yaşanan sıkıntı iki yönlüdür;

- Vücuttaki bazı duyu ve organlar için zayıflama-kayıp değerlendirmeleri kolayca yapılabilirken (örneğin, gözde görme kaybı gibi), bazı organlar için işlev zayıflaması veya kaybı ölçütünün nasıl değerlendirileceği ve hangi ölçütün esas alınacağı sorun yaratacak niteliktedir. Kılavuzda anatomik yapı ya da fonksiyon kaybının değerlendirmelerde dikkate alınacağı belirtilmiştir. Örneğin, tek böbrekte \%50'lik anatomik kayıp durumu k1lavuza göre uzuv kaybı yaratmaktadır. Ancak böbrek fonksiyonları açısından bu durum işlevin mutlaka \%50 kaybı anlamına gelmediği gibi, alınmayan kısmın bir süre sonra kompanzasyon ile fonksiyonunu artırabilmesi de mümkündür. $\mathrm{Bu}$ tür durumlarda ilk değerlendirme kişideki kalıcı fonksiyon kaybı ile uyumsuz hale gelmektedir. Buna benzer örnekler çoğaltılabilir. Bu tür durumlarda "anatomik kayıp" yerine "kalıcı fonksiyonel kayıpların" değerlendirilmesi daha uygun bir yaklaşım olacaktır.

- Birçok organ veya vücut kısmı için net bir şekilde fonksiyonel azalma oranının belirlenmesini sağlayacak ölçüt belirtilmemiştir. Örneğin, üst ekstremitedeki fonksiyon kaybı için \%10 ile elin fonksiyonlarının \%10’u farklı kavramlardır. Bu tür durumların nasıl kolaylıkla ve uygulamada birlik sağlayacak şekilde değerlendirilebileceği ile ilgili olarak kılavuzun basitlik, hakkaniyet ve uygulanabilirlik ölçütleri açısından tekrar gözden geçirilmesi gereklidir.

- Kayıp oranlarının yüzde olarak belirlenmesi konuyu daha da karmaşıklaştırmaktadır. Yukarıda da belirtildiği gibi k1lavuzda her organ veya fonksiyon için ayrı 
ayrı fonksiyon kaybının tespitine yarayan bir düzenleme yoktur. Bu amaçla engellilik tespitine yarayan mevzuat değerlendirmelerde destek amacıyla sıklıkla kullanılmaktadır. Travmalar sonrasında tazminat belirlenmesine yönelik olan ve travma sekellerinin bireyselleştirerek (yaş, meslek vb.) hesaplanmasına izin veren, bu nedenle aynı lezyonda yaşa ve mesleğe göre farklı oranlar hesaplanmasına neden olan, meslekte kazanma gücü kaybı oranının hesaplanmasına yarayan "Malüliyet Tespit İşlemleri Yönetmeliği”" (Resmi Gazete: 03.08.2013/28727) bu amaçla kullanılmamalıdır. Yaş ve meslekten etkilenmeyen, ancak genel maluliyeti belirleyen "Özürlülük Ölçütü, Sınıflandırılması ve Özürlülere Verilecek Sağlık Kurulu Raporları Hakkında Yönetmelik (Resmi Gazete: 30.03.2013/28603) içinde yer alan düzenlemeler yardımcı olarak kullanılabilir. Bu düzenlemeler içinde de organlara özgü değerlendirme yapılmasina izin veren kriterlerin karar vermede yardımcı olarak kullanılması mümkündür. Ancak sık karşılaşılan bazı travma sekelleri için ölçütlerin daha uygulanabilir olarak kılavuz içinde belirlenmesine ihtiyaç vardır.

- Kılavuzdaki bazı belirlemelerin objektif bir ölçütü olmadığı gibi, kendi içinde çelişkisi vardır. Örneğin, k1lavuz açıklamalarında \%10-50 kayıp işlevde zayıflama, $\% 50$ 'den fazla kayıp işlev yitirilmesi olarak açıklanırken, ekli tabloda tek göz görmesinde 4/10 görmeye kadar kayıplar (\%60'a kadar) zayıflama, 3/10 görme veya daha fazla kayıplar (\%70 ve üzeri) işlev kaybı olarak ifade edilmektedir. Kılavuzdaki bu tür çelişkiye sebep olabilecek durumlar giderilmelidir.

- Kılavuzda zayıflama oranı için esas alınan \%10 oranı da bir diğer eleştiri konusudur. Ölçülülük ilkesi gereğince nitelikli hal olduğu değerlendirildiğinde, zayıflama kavramından "organ ve duyunun olağan işlevini önemli derecede azaltan-sınırlayan kayıplar" anlaşılmalıdır. Aynı şekilde "kayıp kavramindan da o organ ve duyunun olağan işlevlerini artı yerine getiremeyecek derecede fonksiyon azalmasının" olması anlaşılmalıdır. Oysa zayıflama için kılavuzda önerilen \%10 kayıp oranı birçok duyu ve organ için fonksiyonun yerine getirilmesine önemli derecede engel olmayacak bir orandır. Örneğin, tek gözde \%10’luk görme kaybı toplumda çok sayıda bireyde bulunan, sıklıkla gözlükle bile düzeltme gerektirmeyen bir durumdur. Bu nedenle kayıp ve azalma için belirlenen oranlar bilimsel, tıbbi ve fonksiyonel açıdan değerlendirilerek tekrar tanımlanmalıdır.

\section{Önerilerimiz}

- Duyu kavramı üzerinde tartışma olmamakla birlikte organ kavramında "tek başına bir görevi/fonksiyonu yerine getirme" kriterinin esas alınmasının uygun olacağ değerlendirilmektedir. $\mathrm{Bu}$ nedenle, değerlendirilmesi gereken ana unsur anatomik kayiptan ziyade, fonksiyon kaybı olmalıdır. Fonksiyon kayılarının bilimsel kriterler 1şığında belirlenmesi için ayrı bir çalışma yapılması uygun olacaktır.

- Zayıflama için belirlenen $\% 10$ oranı, kayıp için \%50 oran1, ölçülülük ilkesine uygun değildir. \% 10'luk bir fonksiyonel kayıp birçok organ veya fonksiyon için olağan işlevi önemli derecede azaltan/sınırlayan bir duruma neden olmamaktadır. Önerimiz, zayıflama için (organ ve duyunun olağan işlevini önemli derecede azaltan-sınırlayan kayıplar için); \% 40-80 arasındaki fonksiyon kayıplarının; kayıp için ise (organ ve duyunun olağan işlevlerini artı yerine getiremeyecek derecede fonksiyon azalmast) $\% 80$ ve daha fazla kayıpların dikkate alınmasının uygun olacağı yönündedir. Ancak bu konunun da yapılacak bir konsensüs toplantısında netleştirilmesi gerektiği açıktır.

\section{Yaralanmanın Kişinin Yaşamını Tehlikeye Sokup Sokmadığı Konusunda Somut Koşulların Değerlendirilmemesi, Olası Sonuçların ve Belirsiz Riskin Fail Aleyhine Değerlendirilmesi:}

765 sayılı TCK uygulamalarında yer alan alışkanlıklardan 5237 sayılı TCK uygulamalarına aktarılan en sıkıntılı unsurlardan biri yaralanmanın kişinin "Yaşamını tehlikeye sokan bir duruma neden olup olmadığı” hususudur.

765 sayılı TCK'daki hali "Kişinin hayatını tehlikeye maruz kılması" olan bu unsurun değerlendirilmesinde "travma sonucu oluşan yara ya da diğer zararların hayat için tehlike ve ölüme yol açabilecek nitelikte olması" gibi muhtemel bir tehlike değerlendirilmekteydi (7). Bu nedenle somut olayda kişinin yaşamsal fonksiyonlarında hiçbir bozulma olmasa dahi ölüme yol açabilme riski olan damar yaralanması, iç organ yaralanması, vücut boşluklarına nüfuz eden yaralanmalarda, somut olgudaki bulgular değerlendirilmeksizin, tehlikelilik durumu dikkate alınarak yaralanmanın kişinin hayatını tehlikeye maruz kıldığı rapor edilmekteydi.

5237 sayılı TCK'da yer alan yaralama suçlarının değerlendirilmesinde bu unsur anlam farkı yaratacak şekilde "Yaşamını tehlikeye sokan bir duruma neden olma" olarak belirlenmiştir. Yani kanunun lafzı değişmiş, maruz kılma şeklindeki risk değerlendirmesi, somut riskin belirlenmesini gerektiren "yaşamı tehlikeye sokan bir duruma neden olma" olarak değişmiştir. Bu nedenle, bu kavramdan bahsedilirken artık yaşamı tehlikeye sokan somut durum belirtilmelidir. Ancak 765 sayılı TCK uygulamalarından ithalle kılavuza alınan eski uygulama nedeniyle bu unsur somut durumun değerlendirmesi yerine tehlikelilik değerlendirmesi olarak uygulanmaktadır. Örneğin, somut olguda, yaşamsal tehlike oluşturan hiçbir klinik bulgu ve dayanak ol- 
masa da sadece damarın yaralanmasının kanama ile ölüme yol açma riski yaratmasından bahisle, "Yaşamını tehlikeye sokan bir duruma neden olduğu" rapor edilmektedir.

Kılavuzdaki açıklama ve örneklerden somut durum yerine, tehlikeliliği değerlendiren bir kavram olarak alg1landığı anlaşılan bu husus, somut olayda kişinin yaşamını tehlikeye sokan durum oluşmamış olsa bile bunun rapor edilmesine neden olabilmektedir.

Kılavuzda kafa travmalarında Glaskow Koma Skoruna göre (8 ve altı), iç organ yaralanmaları, zehirlenme ve asfiksi gibi bazı durumlarda yaşamsal tehlikeden bahsedilmesi için dikkate alınacak somut klinik kriterler açık ve net şekilde belirlenmiştir. Ancak damar yaralanması, elektrik çarpması, organ yaralanmaları gibi durumlarda da yaşamsal tehlike olup olmadığı hususunda aynı netlikte ve somut klinik bulguları doğru şekilde yansıtır değerlendirme kriterleri yoktur. Bu nedenle bazı lezyonlarda somut olgu değerlendirilirken, bazı durumlarda soyut tehlikelilik esas alınmıştır. Hak kaybına ve adli yanılgıya neden olmamak üzere mekanik, genel ve somut olguyu yansıtmayan değerlendirmeleri önlemek için bunlara özgü somut kriterlerin de konulması gereklidir.

Bir diğer sorun şüpheli klinik lezyonların değerlendirilmesidir. Tıbbi görüntüleme olanaklarının artması nedeniyle tespit edilen ve klinik olarak izlenen şüpheli lezyonların (batın içinde az miktarda sıvı, organda kapsül altı sıvı koleksiyonu, şüpheli kırıklar vb) kişilerin yaşamsal fonksiyonlarında hiçbir bozulma bulgusu göstermese ve klinik olarak olup olmadıkları kesinleştirilmese dahi özellikle Adli Tıp Uzmanı olmayan kişilerce yaşamsal tehlike oluşturdukları şeklinde rapor edilebilmektedir. Şüpheden sanığın yararlanması ilkesine taban tabana zit bu uygulama nedeniyle şüpheli lezyonlar çoğu kez sanık aleyhine sonuç doğuracak şekilde kullanılmaktadır. Bu sebeple, tıbbi muayene ve tetkikler ile kesinleştirilmemiş bulguların sanık aleyhine raporlanmaması sağlanmalıdır.

\section{Kemik kırıklarının ve çıkıklarının hayat fonksiyonlarına etkisinin değerlendirmesi:}

Kemik kırıklarının ve çıkıklarının "Hayat Fonksiyonlarına Etkisi” açısından değerlendirme 5237 sayılı TCK ile getirilen yeni bir kavram olmuştur. Bu nedenle eski alışkanlıkların yeni kılavuza aktarılması bu değerlendirmelerde söz konusu olmamış, ancak değerlendirmenin nasıl yapılacağı konusunda büyük bir sıkıntı ortaya çıkmıştır. Kılavuzdaki hali ile "Hayat Fonksiyonlarından" ne anlaşılması gerektiği tartışmalıdır. Kemiklerde oluşan kırıklar için belirli bir skor belirlenmiş ve birden çok kırık-çıkık olması halinde bunların karelerinin toplamının karekökünün alınması şeklinde bir hesaplama önerilmiştir.
Öncelikle "Hayat Fonksiyonları" kavramının doğru anlaşılması ve değerlendirilmesi gereklidir. "Hayat Fonksiyonları" kavramı, "Hayat İşlevleri-Hayati Fonksiyonlar" kavramından farklı olduğu gibi "Travmanın şiddeti veya kemiğin kırılması için uygulanacak kuvvetten" de farklıdır. Bu kavram ile günlük yaşamda yapılan ortak, alışlagelmiş hareketler ve fonksiyonlar üzerine etki anlaşılmalıdır (11). Kanundaki düzenlemenin her zaman doğru sonuç doğurmayacağı, bunun yerine mağdurun yaşantısının dikkate alınması gerektiği konusunda eleştiriler vardır (12).

Kılavuzda kemik kırık ve çıkıkları skorlanırken, kırı$\breve{g}$ ın hayat fonksiyonlarının hangisine, nasıl etki ettiğinin hangi kriterlerle belirlendiği anlaşılmamaktadır. Kırıklarda "Hayat fonksiyonlarına etki" kavramının kanunda ifade ettiği anlam tekrar gözden geçirilerek daha kolay uygulanabilir bir önerinin getirilmesi gereklidir. Halen uygulamada kanunun lafżna uygun olmayan şekilde standart bir skorlama yapılmaktadır. Bu nedenle dikkate alınan unsurun somut olaydaki olgunun hayat fonksiyonlarından ziyade soyut ve genel bir değerlendirme olduğu açıktır.

Skorlama yapılırken aynı kemikte birden çok kırık olsa da bunlardan sadece en ağırının dikkate alındığı görülmektedir. Yine birden fazla kemik kırı̆ğındaki skorların birleştirilme yolunun neden bu şekilde bir hesaplama yolu olarak seçildiği net şekilde açıklanmamıştır. Karmaşık bir matematiksel hesaplama gerektiren bu durum uygulamada zorluk yaratmaktadır.

2013 yılında güncellenen kılavuzda elde edilen toplam skora göre hafif/orta/ağır derece için bir açıklamaya yer verilmediği, bu ayrımın/açıklamanın 2005 yılındaki k1lavuzda örnekleriyle, ayrıntılı olarak verildiği görülmektedir. Uygulamada skor 1 ise hafif, 2-3 ise orta, 4 ve üstünde ise ağır derecede hayat fonksiyonlarını etkilediği rapor edilmektedir. Sadece 2013 y1lında güncellenen k1lavuza bakarak raporlama yapan adli tıp uzmanı olmayan bir hekimin hafif/orta/ağır derecelemesini nasıl ve neye göre yapacağı konusunda sorun yaşayabileceği açıktır.

\section{Önerilerimiz:}

- Kırık ve çıkıkların hayat fonksiyonlarına etkisi değerlendirilirken, k1lavuzdaki gibi bir skorlama yerine daha basit, anlaşılabilir ve uygulanabilir bir yöntem kullanılabilir.

- Skorlama basitleştirilebilir. Örneğin;

- "El veya ayak parmak kemiklerinde en fazla iki kırık veya çıkık, iki veya daha az kaburga kemik kırığı, nazal kemik uç kısım kırığı, pelvik kemiklerde küçük kopma kırı̆̆ı" için hafif;

- "Üç veya daha fazla kaburga, el parmak kemiği kırığı, ulna, radius, fibula kırığı" için orta; 
- "Vertebra, femur, tibia, pelvik kemik kırıkları, kafatası kemik kırıkları" için ağır değerlendirmesi yapılması kılavuzdaki skorlama sonucu bulunan sonuçlarla neredeyse tamamen uyuşmaktadır. Böylece ayrı bir skorlamahesaplama yapmaya gerek duyulmayacak şekilde, değerlendirme basitleștirilebilir.

- Kılavuzda daha ağır ve hafif kırıklar için aynı skorun kullanıldığı durumlar gözden geçirilip düzeltilmelidir.

\section{Taksirle yaralamalarda BTM ve kırık-çıkık skor- lamasının gereksizliği:}

Taksirle yaralama suçlarının değerlendirilmesi ile ilgili 89. madde incelendiğinde yaralanmanın etkilerinin BTM ile giderilebilir olup olmadığ unsurun yer almadığ kırık olup olmadığının değerlendirildiği görülmektedir. Oysa uygulamada adli rapor taleplerinde adli makamlarca siklıkla bu unsurların da sorulduğu veya sorulmasa da raporlarda kalıp olarak bunların da rapor edildiği görülmektedir.

\section{Sonuç}

Yaralanma olguları ile ilgili yapılan değerlendirmelerde somut olayın sonuçlarını, soyut ve genel bazı değerlendirmeler çerçevesinde yapmaya çalışmak raporlamada bir standardizasyon getirmiş olsa da, somut olayın sonuçlarının bazı olgularda objektif şekilde değerlendirilmesine mani olarak yargılamalarda adaletsizliklere neden olabilecek niteliktedir.

Tiptaki "Hastalık yoktur, hasta vardır", özdeyişinin hukuktaki karşıllı̆̆ olan "Somut olayın özelliklerine göre" özdeyişi ile belirtildiği şekilde, yaralama olguları arasındaki farklılıkları tam yansıtmayan, kalıplaşmış değerlendirme mekanizmalarının, yaralama suçlarında kullanılmasının her zaman sıkıntıya ve adli yanılgıya yol açması olasıdır. Bunun yerine, her yaralama olgusunda, yaralamanın sonuçlarını ve nitelikli hallerini, kanunun ruhu ve lafzı ile uygun şekilde, daha objektif ve somut olguyu gerçekten yansıtır şekilde değerlendirebilmesini sağlayacak şekilde raporlama yapılması gerekliliği açıktır.

Kılavuz konusunda yapilan eleştirilere yanıt olarak sıklıkla, "hekimin yaptığ işlemin tıbbi bir değerlendirme olduğu, hukuki işlem ve değerlendirmelerin ise hu- kukçulara ait olduğu" yanıtı verilmektedir. Ancak adli tıbbi değerlendirmelerin iki mesleğin kesişme noktasında bulunduğu açıktır. Bu nedenle raporlama yapan hekimin, travmanın adli anlamını bilmesi, yani hukukçunun yaralama suçunu değerlendirmek için hangi özellik ve sonuçları aradığını, aranmasını istediği hususları nasıl nitelendirdiğini bilerek değerlendirme yapması gereklidir. Travma için TCK'da yer alan unsurların adli anlamlarını, ceza usul işlemlerini nasıl etkilediğini asgari düzeyde bilmeden yapılacak "Adli-Tıbbi" değerlendirmelerin ceza kanunlarının amaçlarını yerine getirmede yetersiz/hatalı olacağı akılda bulundurulmalıdır.

\section{Kaynaklar}

1. Özbek VÖ, Kambur MN, Doğan K, Bacaksız P, Tepe İ. Türk Ceza Kanunu Genel Hükümler. Seçkin Yayınevi, Beşinci Bask1, 2014.

2. Türk Ceza Kanunu, Kanun No: 5237. Resmi Gazete Tarih ve Sayıs1: $12.10 .2004 / 25611$.

3. Yeni Türk Ceza Kanunu'nda Tanımlanan Yaralama Suçlarının Adlî Tıp Açısından Değerlendirilmesi Kılavuzu. Editörler: Uz. Dr. Sadullah Güzel, Doç. Dr. Yasemin Balcı, Prof. Dr. Gürsel Çetin.

4. Türk Ceza Kanunun Yürürlük ve Uygulama Şekli Hakkında Kanun, Kanun No: 5252. Resmi Gazete Tarih ve Say1s1: 13.11.2004/25642.

5. Sağlık Bakanlığı Temel Sağlık Hizmetleri Genel Müdürlüğünün 22.09.2005 tarih, 2005/143 say1lı Genelgesi.

6. Sağlık Bakanlığı Sağlık Hizmetleri Genel Müdürlüğünün 26.09.2014 tarih, 2014/29 say1l Genelgesi.

7. Soysal Z, Çakalır C, editörler. Adli Tip: Adli Tıpta Rapor Hazırlama Tekniği ve Rapor Örnekleri (Yazar: Koç S.) İstanbul Üniversitesi Cerrahpaşa Tıp Fakültesi Yayınları, 1999. Cilt III, s. 1582.

8. Yargitay 3. Ceza Dairesi, 2014/36581 Esas, 2015/13266 Karar nolu kararı.

9. Yargitay 2. Ceza Dairesi, 2011/1629 Esas, 2012/42892 Karar nolu kararı.

10. Bayraktar B, Yücesir İ. Yumuşak Doku Yaralanmaları, İyileşme Süreci ve Tedavi Yaklaşımları. Klinik Gelişim Dergisi, 22(1):60-67, 2009.

11. Çetin G. İstanbul Üniversitesi Cerrahpaşa Tıp Fakültesi Adli Tıp Ders Kitabı-Türk Ceza Kanunu Açısından Yaralanmalar. İstanbul Üniversitesi Yayınları, No:4898, s:211. Basım Yı11: 2011.

12. Tezcan D, Erdem MR, Önok RM. Teorik ve Pratik Ceza Özel Hukuku. Seçkin Yayınevi. Güncellenmiş 12. Baskı. 2015, s. 247. 